\title{
Peluang Bisnis Multimedia di Era Pandemi Covid-19
}

\author{
Agung Putra Raneo ${ }^{1^{*}}$, Kemas Muhammad Husni Thamrin $^{1}$, Dessy Yunita ${ }^{1}$, Asfeni Nurullah $^{1}$ \\ ${ }^{1}$ Fakultas Ekonomi, Universitas Sriwijaya, Sumatera Selatan, Indonesia \\ *Email korespondensi: agung.raneo@fe.unsri.ac.id; Phone: +62 8127340990
}

Info Artikel: Diterima: 15 Desember 2020; Disetujui: 01 Oktober 2021; Dipublikasi: 05 November 2021

\begin{abstract}
Abstrak: Perkembangan dunia bisnis sejalan dengan pertumbuhan teknologi yang makin pesat. Ada hubungan yang saling terkait antara pemanfaatan teknologi dengan bisnis. Begitupun dalam ranah multimedia, banyak hal yang bisa dimanfaatkan untuk memajukan bisnis terutama dalam masa pandemi Covid-19. Berdasarkan data yang dikeluarkan LIPI terdapat sekitar 94,69\% UMKM mengalami dampak negatif pandemi. Oleh sebab itu kegiatan pengabdian ini dilakukan untuk membantu UMKM di Kecamatan IB II dalam mencari peluang bisnis baru yang terkait multimedia. Kegiatan dilakukan dengan metode ceramah, pelatihan dan diskusi.
\end{abstract}

Kata Kunci: Pandemi Covid-19; UMKM; Multimedia

Kutipan:

Raneo, P.A., Thamrin, K.M.H., Yunita, D., \& Nurullah, A. (2021). Peluang Bisnis Multimedia di Era Pandemi Covid-19. Sricommerce: Journal of Sriwijaya Community Services, 2(2): 105-112. DOI: https://doi.org/10.29259/jscs.v2i2.43

\section{PENDAHULUAN}

Perkembangan dunia bisnis saat ini semakin pesat seiring dengan semakin tingginya penggunaan teknologi di masyarakat (Evin \& Rumpak, 2019). Teknologi semakin memiliki peranan penting dalam kehidupan sehari - hari. Hampir semua kegiatan bermasyarakat pasti memiliki kaitan atau peranan teknologi di dalamnya (Rakib at al, 2020). Hal ini membuat munculnya peluang - peluang baru di dunia bisnis yang berkaitan dengan teknologi. Berkaitan dengan atmsofer bisnis, kota Palembang adalah salah satu kota besar di Indonesia yang memiliki perkembanga bisnis yang cukup baik. Berdasarkan data BPS Sumatera Selatan, Palembang memiliki wilayah dengan luas $400,61 \mathrm{~km}^{2}$ dengan jumlah penduduk 1.696.244 orang. Merujuk pada data dari Dinas Koperasi dan UMK Provinsi Sumatera Selatan, jumlah UMKM di Kota Palembang pada tahun 2020 berjumlah 37. 351 UMKM. Dari data tersebut jenis usaha yang dominan adalah kuliner. Data - data tersebut menunjukan bahwa kota Palembang memiliki potensi yang besar di sektor bisnis.

Seiring dengan perubahan situasi terkini, yaitu munculnya wabah Covid-19, membuat situasi sosial maupun bisnis berubah drastis (Marlinah, 2020). Wabah virus tersebut membuat banyak hal harus disesuaikan (Sumarni, 2020). Hal ini juga merambah ke ranah bisnis. Dalam survei yang dilakukan oleh Lembaga IImu Pengetahuan Indonesia (LIPI) melalui Pusat Penelitian Ekonomi (P2E) menunjukkan hasil bahwa selama pandemi, sebanyak 94,69\% pelaku UMKM terdampak negatif COVID-19. Bisnis - bisnis konvensional banyak bertumbangan karena tidak ada konsumen yang datang ke tempat karena kebijakan jaga jarak dan dirumah saja. Hal ini terutama terdampak pada sektor UMKM (Dwijayanti \& Pramesti, 2021). Kondisi ini membuat sistem bisnis berubah. Ada hal - hal baru yang harus disesuaikan. Diluar dai situasi buruk yang muncul tetap saja ada peluang yang bisa dimanfaatkan. Salah satu hal yang bisa dimanfaatkan adalah pengoptimalan penggunaan teknologi untuk diterapkan ke pola - pola bisnis konvensional (Avriyanti, 2021). Salah 
satu bisnis yang masih bisa bertahan dan di era pandemi Covid-19 ini adalah bisnis di bidang multimedia (Andaiyani et.al., 2020).

Peranan bisnis dalam ekonomi suatu negara adalah besar, terutama sektor bisnis UMKM (Narto \& Basuki, 2020). Sektor tersebut menjadi tulang punggung agar roda ekonomi terus berputar, apalagi di masa pandemi seperti ini. Diperlukan banyak UMKM yang tetap buka. Hal ini juga menuntut untuk adanya literasi mengenai kewirausahaan di kalangan anak muda agar pola pikir mereka tidak hanya mencari kerja tapi membuka lapangan pekerjaan. Dalam jurnal (Basyah, Fahmi \& Razak, 2020) menyatakan bahwa wirausaha adalah bagai suatu bibit pohon bagi perekonomian suatu negara, semakin banyak bibit nya maka akan semakin banyak pohon yang tumbuh dan membuat rimbun dan sejuk.

Berdasarkan definisi yang dikutip dari (Hofstetter, 2001), multimedia mempunyai arti pemanfaatan komputer dalam menyajikan dan menggabungkan bentuk berupa animasi, video, gambar, suara dan juga teks melalui alat bantu dan juga jaringan sehingga melalui hal - hal tersebut dapat dilakukan kegiatan navigasi, interaksi, berkarya dan juga berkomunikasi. Pengertian multimedia lainnya terdapat di buku (Robin, 2001) yaitu suatu alat yang dapat digunakan untuk membuat kegiatan presentasi menjadi lebih interaktif dan dinamis melalui kombinasi antara video, grafik, audio, teks dan juga animasi. Dari definisi - definisi tersebut memberi peluang untuk munculnya bisnis - bisnis baru maupun bisnis - bisnis lama untuk dikembangkan dengan sentuhan multimedia.

Bagaimana penerapan konsep multimedia di dalam bisnis terutama untuk UMKM dapat dicontohkan melalui usaha pempek. Di tengah wabah Covid-19 akan sulit untuk mengharapkan tingkat penjualan yang baik jika pola bisnis masih konvensional yaitu berharap konsumen yang datang. Maka, solusi yang dapat kita lakukan adalah dengan membuat pempek kita yang mendatangi konsumen melalui konsep multimedia. Bisa dengan memanfaatkan aplikasi jualan online atau marketplace. Dalam jurnal (Faridah \& Wulandari, 2020), mereka membahas mengenai pemanfaatan marketplace untuk masyarakat di Desa Sidomukti, Lamongan selama masa pandemi Covid-19 dan diperoleh simpulan bahwa masih banyak masyrakat yang masih takut untuk memanfaatkan peran marketplace dalam usaha mereka. Melalui multimedia yang lebih interaktif maka peluang untuk mendapatkan pelanggan semakin besar (Hagen \& Golombisky, 2019).

Dengan melihat kondisi pandemi Covid-19 sekarang dan karakter bisnis UMKM di Palembang, maka pengabdian menyasar pada pemaparan peluang multimedia dalam membuat bisnis tetap stabil dan berjalan. Diharapkan dengan adanya penjelasan mengenai konsep multimedia akan membuat pelaku usaha di kota Palembang bisa tetap eksis usaha dan kegiatan bisnisnya.

\section{STUDI PUSTAKA}

\subsection{Pengertian Multimedia}

Menurut (Hofstetter, 2001), multimedia mempunyai arti pemanfaatan komputer dalam menyajikan dan menggabungkan bentuk berupa animasi, video, gambar, suara dan juga teks melalui alat bantu dan juga jaringan sehingga melalui hal - hal tersebut dapat dilakukan kegiatan navigasi, interaksi, berkarya dan juga berkomunikasi. Dalam buku (Robin, 2001), yaitu suatu alat yang dapat digunakan untuk membuat kegiatan presentasi menjadi lebih interaktif dan dinamis melalui kombinasi antara video, grafik, audio, teks dan juga animasi.

Kegiatan bisnis dengan memanfaatkan multimedia artinya memberi sentuhan lebih dalam hal visual dan audio agar lebih menarik minat calon pembeli (Rahmi \& Fauzi, 2020). Dalam buku (Suyanto, 2004) menjelaskan bagaimana penjualan dapat meningkat dengan tambahan unsur multimedia.

\subsection{Pandemi Covid - 19}


Menurut WHO, Corona Virus Disease 2019 atau disingkat COVID-19 adalah sebuah pandemi. Hal tersebut ditetapkan di Genewa, Swiss pada Rabu, 11 Maret 2020. Pandemi sendiri diartikan sebagai skala penyebaran penyakit yang terjadi secara global di seluruh dunia. Kondisi ini memberi dampak besar di berbagai bidang seperti ekonomi, politik, sosial, budaya, pertahanan dan keamanan, hal ini menunjukan perlunya upaya dan strategi yang tepat dari pemerintah dalam penanganan COVID-19. Penanggulangan Covid-19 memunculkan istilah baru dalam sosial masyarakat yaitu new normal atau normal baru, suatu istilah yang menggambarkan suatu perubahan dalam perilaku untuk tetap bisa menjalankan aktivitas secara normal namun ditambah dengan menerapkan protokol kesehatan guna mencegah terjadinya penyebaran COVID-19. (Gugus Tugas Percepatan Penanganan COVID-19, 2020). Untuk mencegah proses penularan dan penyebaran COVID-19 di Indonesia yang semakin mengkhawatirkan, pemerintah melakukan tindakan darurat melalui Kepres Nomor 11 Tahun 2020 yaitu menetapkan Kedaruratan Kesehatan Masyarakat Corona Virus Disease 2019 (COVID-19).

\subsection{Pengertian Usaha Mikro, Kecil, dan Menengah}

Merujuk pada Pasal 1 Undang-Undang Nomor 20 Tahun 2008, yang dimaksud dengan usaha Mikro ialah usaha produktif milik orang perorangan dan/atau badan usaha perorangan yang memenuhi kriteria memiliki kekayaan bersih paling banyak Rp50.000.000,00 (lima puluh juta rupiah) tidak termasuk di dalamnya tanah dan bangunan tempat usaha; atau memiliki hasil penjualan tahunan paling banyak Rp300.000.000,00 (tiga ratus juta rupiah). Usaha Kecil ialah usaha ekonomi produktif yang berdiri sendiri, yang dilakukan oleh orang perorangan atau badan usaha yang bukan merupakan anak perusahaan atau bukan cabang perusahaan yang dimiliki, dikuasai, atau menjadi bagian baik langsung maupun tidak langsung dari Usaha Menengah atau Usaha Besar yang memenuhi kriteria memiliki kekayaan bersih lebih dari Rp50.000.000,00 (lima puluh juta rupiah) sampai dengan paling banyak Rp500.000.000,00 (lima ratus juta rupiah) tidak termasuk tanah dan bangunan tempat usaha; atau memiliki hasil penjualan tahunan lebih dari Rp300.000.000,00 (tiga ratus juta rupiah) sampai dengan paling banyak Rp2.500.000.000,00 (dua milyar lima ratus juta rupiah).

Usaha Menengah ialah usaha ekonomi produktif yang berdiri sendiri, yang dilakukan oleh orang perorangan atau badan usaha yang bukan merupakan anak perusahaan atau cabang perusahaan yang dimiliki, dikuasai, atau menjadi bagian baik langsung maupun tidak langsung dengan Usaha Kecil atau Usaha Besar dengan memiliki kekayaan bersih lebih dari Rp500.000.000,00 (lima ratus juta rupiah) sampai dengan paling banyak Rp10.000.000.000,00 (sepuluh milyar rupiah) tidak termasuk tanah dan bangunan tempat usaha; atau memiliki hasil penjualan tahunan lebih dari Rp2.500.000.000,00 (dua milyar lima ratus juta rupiah) sampai dengan paling banyak Rp50.000.000.000,00 (lima puluh milyar rupiah) (UU Republik Indonesia Nomor 20 tahun 2008 tentang UMKM).

\section{METODE PELAKSANAAN}

Metode yang dilakukan dalam kegiatan pengabdian masyarakat ini adalah dengan pembagian materi, presentasi, serta diskusi dan tanya jawab. Adapun susunan materi dalam kegiatan pengabdian ini adalah sebagai berikut:

1. Memberikan materi tentang multimedia.

2. Memberikan materi tentang sosial media

3. Memberikan materi tentang pemanfaatan multimedia dan sosial media dalam bisnis

4. Memberikan materi tentang bisnis - bisnis yang terkait multimedia.

Adapun khalayak sasaran kegiatan pengabdian masyarakat yang dipilih adalah adalah para pelaku UMKM yang ada di Kecamatan Ilir Barat II, Palembang. Adapun peserta kegiatan pengabdian masyarakat ini sebanyak 25 orang.

\section{HASIL DAN PEMBAHASAN}




\subsection{Pelaksanaan Kegiatan}

Pelaksanaan pengabdian masyarakat dilakukan di Kantor Kecamatan Ilir Barat II Palembang yang beralamat di Jl. Makrayu 32 Ilir Palembang. Peserta adalah para pelaku UMKM di Kecamatan Ilir Barat II Palembang.

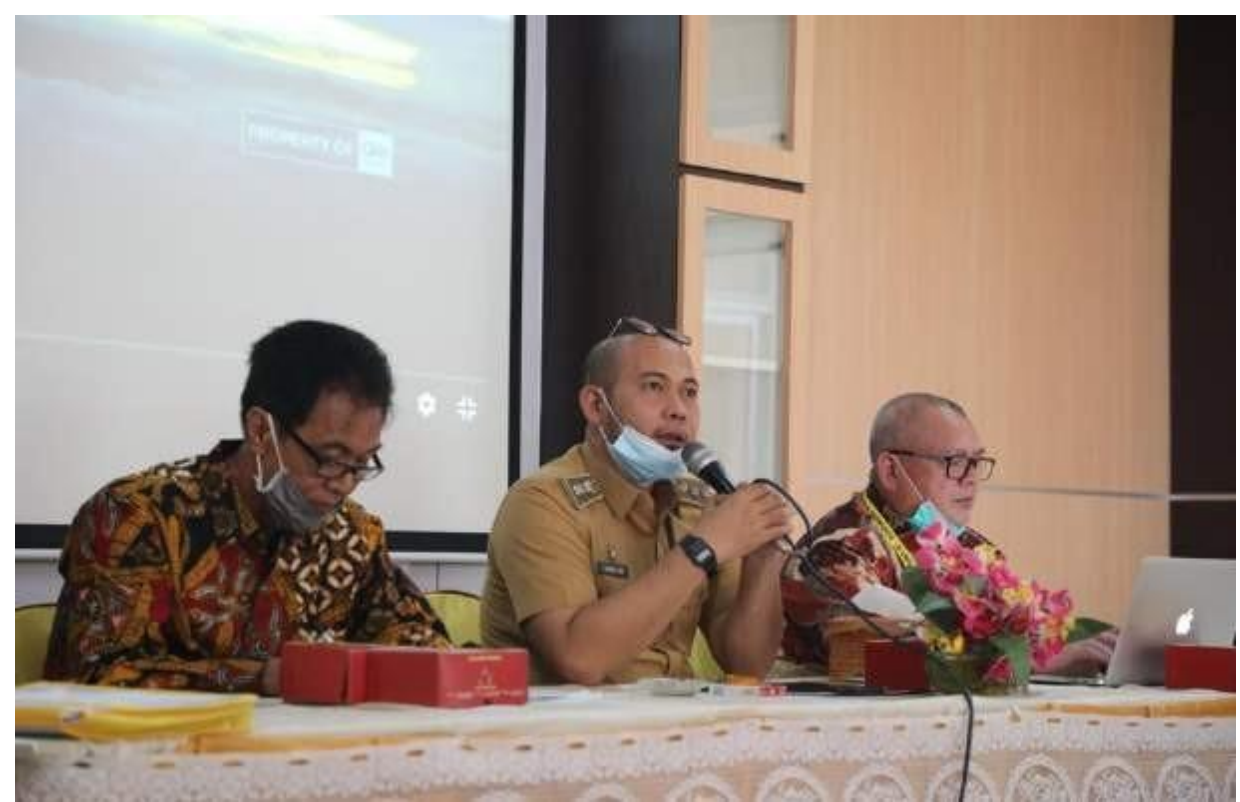

Gambar 1. Acara Dibuka oleh Sambutan dari Camat Ilir Barat II

Acara kegiatan pada masyarakat ini dibuka dengan kata sambutan dari perwakilan dari Fakultas Ekonomi Universitas Sriwijaya (FE Unsri), dalam hal ini diwakili oleh Wakil Dekan III FE Unsri, Bapak Drs. H. Dian Eka, M.M. Kemudian dilanjutkan dengan kata sambutan dari Bapak Camat Ilir Barat II Palembang, Bapak Hambali, S.STP sekaligus juga secara resmi membuka acara pengabdian ini. Kegiatan ini diikuti oleh 25 orang pelaku UMKM di wilayah Kecamatan Ilir Barat II Palembang.

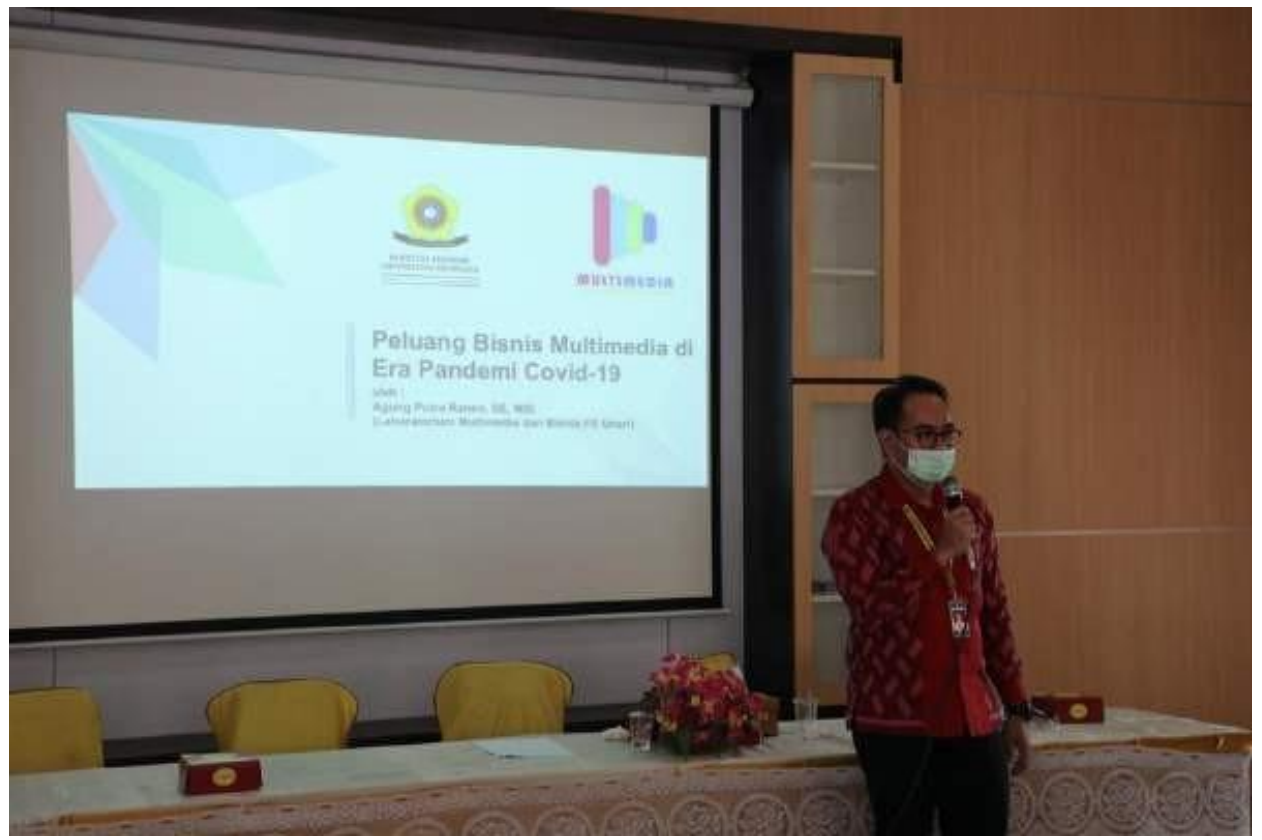

Gambar 2. Paparan oleh Tim Pelaksana 
Memasuki acara inti kegiatan pengabdian pada masyarakat ini, peserta diberikan pelatihan mengenai:

1. Konsep dasar multimedia

2. Konsep dasar sosial media

3. Memanfaatkan multimedia dan sosial media dalam mengembangkan bisnis

4. Bisnis - bisnis yang terkait multimedia.

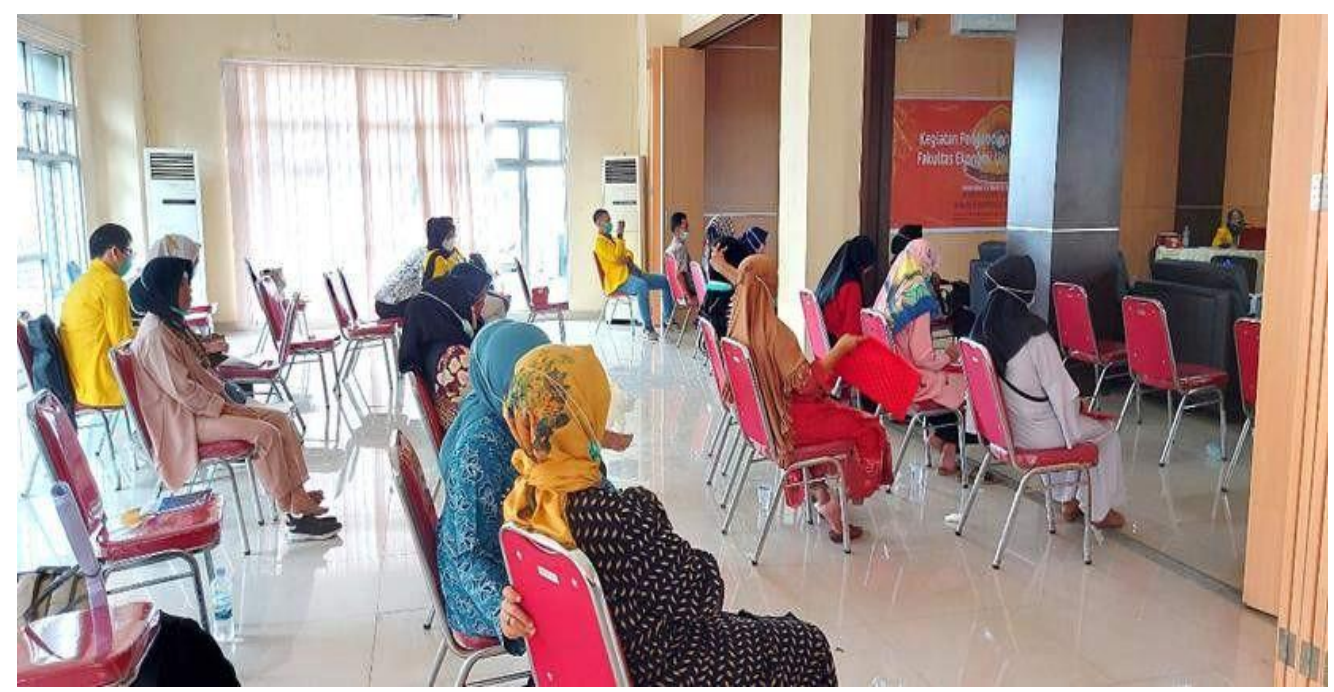

Gambar 3. Antusiasme Peserta dalam Mengikuti Pelatihan

Setelah memberikan pelatihan tentang "Peluang Bisnis Multimedia di era Pandemi Covid-19", acara kemudian dilanjutkan ke pertanyaan atau peserta dengan para hadirin. Dalam kegiatan ini peserta sangat antusias karena bisa bertanya langsung dan menyampaikan kendala-kendala serta permasalahan yang dihadapi UMKM di masa pandemi. Kebanyakan pelaku UMKM di Kecamatan IB II masih belum terbiasa dalam memanfaatkan internet. Melalui basis internet, para pelaku UMKM dapat memanfaatkan media sosial dalam mengembangkan pemasaran produknya (Susanti, 2020).

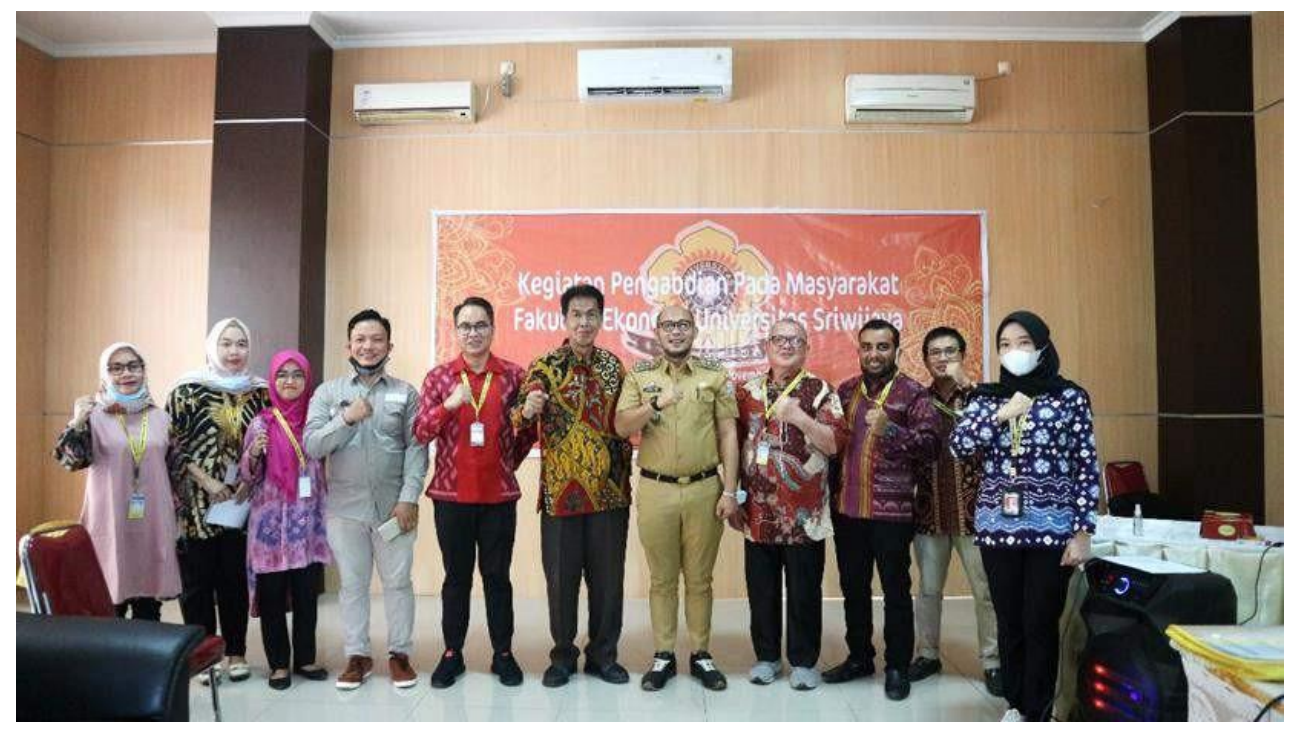

Gambar 4. Foto Bersama dengan Camat Ilir Barat II Palembang

Dalam kegiatan pengabdian dengan judul Peluang Bisnis Multimedia di era Pandemi Covid-19 ini, peserta juga diberikan kesempatan untuk memberikan kritik, saran, dan evaluasi atas penyelenggaraan kegiatan pada masyarakat ini. Dari hasil kuesioner yang didapat, Sebagian besar 
masyarakat merasakan manfaat dan sangat antusias agar kegiatan serupa dapat dilaksanakan kembali di masayang akan datang. Pada hari Jumat, 13 November 2020, rangkaian acara kegiatan pengabdian pada masyarakat di Kecamatan Ilir Barat II Palembang ditutup dengan Penandatanganan Kerjasama (MOA) antara Fakultas Ekonomi Universitas Sriwijaya dengan Camat Ilir Barat II Palembang. MOA ini merupakan kesepakatan untuk pendampingan dan pemberdayaan pelaku UMKM di wilayah Kecamatan Ilir Barat II.

\section{SIMPULAN}

Kesimpulan dari pelaksanaan pengabdian kepada masyarakat ini didapatkan bahwa rata - rata pelaku UMKM di Kecamatan Ilir Barat II Palembang belum mempunyai pemahaman mengenai konsep multimedia, sosial media dan pemanfaatannya untuk bisnis.Pelaku UMKM di Kecamatan Ilir Barat II Palembang juga sangat antusias dengan materi dan kegiatan pelatihan.

\section{UCAPAN TERIMA KASIH (ACKNOWLEDGMENTS)}

Kegiatan Pengabdian kepada Masyarakat ini didanai oleh Dipa dan Rincian Belanja Satuan Kerja Fakultas Ekonomi Universitas Sriwijaya. Atas terselenggaranya pelaksanaan acara Pengabdian Kepada Masyarakat ini diucapkan terima kasih kepada pihak Rektor Universitas Sriwijaya atas arahannya dalam kegiatan Pengabdian Kepada Masyarakat, pihak koordinator UPPM Fakultas Ekonomi Universitas Sriwijaya atas arahan dan bimbingannya dalam kegiatan Pengabdian kepada Masyarakat dan pihak dekan Fakultas Ekonomi Universitas Sriwijaya atas arahan dan bimbingannya dalam kegiatan. Kepada Bapak Camat Ilir Barat 2 atas bantuan izin dan pengarahannya serta seluruh masyarakat pelaku UMKM di Kecamatan Ilir Barat II atas partisipasi dan kerjasama yang baik. Dan seluruh Tim Pelaksana Kegiatan Pengabdian kepada Masyarakat Universitas Sriwijaya tahun 2020.

\section{REFERENSI}

Andaiyani, S., Yunisvita, Y., \& Tarmizi, N. (2020). Peran Financial Technology sebagai Alternatif Permodalan bagi UMKM di Desa Kerinjing, Kabupaten Ogan Ilir. Sricommerce: Journal of Sriwijaya Community Services, 1(2), 85-92. doi:https://doi.org/10.29259/jscs.v1i2.16

Avriyanti, S. (2021). Strategi Bertahan Bisnis di Tengah Pandemi Covid-19 Dengan Memanfaatkan Bisnis Digital (Studi Pada UKM Yang Terdaftar Pada Dinas Koperasi, Usaha Kecil dan Menengah Kabupaten Tabalong). Jurnal PubBis. 5(1), 60-73.

Basyah, Ali, N., Fahmi, I., \& Razak, A. (2020). Pendidikan Kewirausahaan Masa Covid-19 : Satu Tinjauan. Jurnal Pencerahan. 14(1), 1-11.

Dwijayanti, A., \& Pramesti, P. (2021). Pemanfaatan Strategi Pemasaran Digital Menggunakan ECommerce Dalam Mempertahankan Bisnis UMKM Pempek4Beradek di Masa Pandemi Covid-19. IKRAITH-ABDIMAS. 4(2), 68-73.

Evin. \& Rumpak. (2019). Analisis Pengembangan Desain Grafis Dalam Aplikasi Photoshop Sebagai Peluang Bisnis Mahasiswa Institut Bisnis dan Multimedia ASMI. Jurnal SISTEM INFORMASI. 1(2), 33-40.

Faridah, F., \& Wulandari, Z.W. (2020). Pendampingan Pemasaran Industri Lokal Melalui Penggunaan Marketplace Untuk Meningkatkan Hasil Produksi Pada Masa Pandemi Covid-19 di Desa Sidomukti Lamongan. Engagement. 4(2), 509-523.

Gugus Tugas Percepatan Penanganan COVID-19. 2020.

Hagen, R \& Golombisky, K. (2017). White Space Is Not Your Enemy : A Beginner's Guide to Communicating Virtually Through Graphic, Web \& Multimedia Design. CRC Press.

Hofstetter, F.T. (2001). Multimedia : Making it Work. $8^{\text {th }}$ Edition. New York : McGraw-Hill. Kepmenkes RI Nomor HK.01.07/MENKES/328/2020 tentang Panduan Pencegahan dan Pengendalian Corona Virus Disease 2019 (COVID-19) di Tempat Kerja Perkantoran dan Industri Dalam Mendukung Keberlangsungan Usaha pada Situasi Pandemi. 
Marlinah, L. (2020). Peluang dan Tantangan UMKM Dalam Upaya Memperkuat Perekonomian Nasional Tahun 2020 Ditengah Pandemi Covid-19. Jurnal Ekonomi. 22(2), 118 - 124.

Narto. \& Basuki, G.H.M.(2020). Penguatan Strategi Pemasaran Pudak di Tengah Pandemi Covid- 19 Untuk Meningkatkan Keunggulan Bersaing Usaha Mikro Kecil Menengah Kota Gresik. Jurnal INTECH. 6(1), 48-54.

Peraturan Pemerintah Republik Indonesia Nomor 21 Tahun 2020 tentang Pembatasan Sosial Berskala Besar.

Rahmi, A., \& Fauzi, M.F. (2020). Membangkitkan Bisnis Kuliner Terdampak Covid-19 Melalui Multimedia. Prosiding Universitas AMIKOM Yogyakarta, 510 -515.

Rakib, M., Syam, A., Marhawati, \& Dewantara, H. (2020). Pelatihan Merancang Bisnis Online di Masa Pandemi Bagi Mahasiswa. Jurnal Dedikasi. 22(2), 129 - 134.

Robin, Linda. (2001). Kitab Suci Komputer \& Multimedia. Yogyakarta : Alberta.

Sumarni, Y. (2020). Pandemi Covid-19 : Tantangan Ekonomi dan Bisnis. Al-Intaj Jurnal Ekonomi dan Perbankan Syariah. 6(2), 46-58.

Survei Lembaga Ilmu Pengetahuan Indonesia. 2020.

Susanti, S. (2020). Peluang dan Tantangan Bisnis Kriya saat Pandemi Covid - 19. Jurnal Pengabdian Pada Masyarakat. 6(2), 381-389.

Suyanto. (2004). Analisis dan Desain Aplikasi Multimedia. Yogyakarta : Andi Undang-undang Republik Indonesia Nomor 20 tahun 2008 tentang UMKM. WHO International. 2020. 
